\title{
Managers in Senegal Facing the Challenges of Ethics and CSR
}

\author{
Moussa Dia \\ Associate Professor in Management at Thies Polytechnic School \\ BP A10 Thies, Senegal \\ Dr. Ngor Sarr \\ Professor at Thies Polytechnic School \\ Senegal \\ Hadiza Moussa-Saley, PhD. \\ Tenured Lecturer and Researcher \\ Applied Mathematics, CESAG \\ Senegal
}

\begin{abstract}
Summary
CSR has always fed on the mainstream of Business Ethics, which invites organizations to take on moral responsibilities towards society. Indeed, ethics has become a new structuring paradigm in the current context of defiance of modern firms. This article attempts to provide some necessary answers to the clarification of the concept in the dynamics of CSR. It seeks to model the managerial ethical posture of the leaders in Senegal. The modeling methods by the structural equations specifically the PLS will be mobilized.
\end{abstract}

Keywords: Managerial Ethics, Corporate social responsibility (CSR), Profit, Partial Least Square Modeling

\section{Introduction}

The crises that hit the worldwide economy in recent years have, shown the limits of our development models based on exacerbated ultra-liberalism. The modern enterprise, especially the multinational company obsessed with the excessive accumulation of richness occupy a prominent place in this ultra-liberalism, is pointed out. Englander and Kaufman (2004) emphasize: "the ethical indifference led to negligence, then to serious errors of judgment, and to prevarication, when it was not pure cynicism".

The company especially the multinational is incriminated and its responsibility is at the heart of the debate with regard to its exorbitant power held in society. It is expected to exercise her responsibility by virtue of the boundless increase of her power. That is to say that beyond their effort for economic prosperity, the modern enterprise will have to respond to societal challenges and respect the environment. These issues of responsibility, commitment to social well-being and choices to be made for the preservation of the environment, fundamentally raise the question of the ethical posture of organizations. This ethical behavior is marked by the managerial continuum whose slider varies from the extreme position of the liberal orthodoxy carried by the Chicago School, which claims that the single responsibility of the company is fiduciary towards its shareholders and that of social voluntarism stemming from the theories of CSR that aims to maximize the collective well-being. The text is structured in three sections. A first section is devoted to the theoretical examination of the question by analyzing the ethical postures of organizations on a series of two basic positions. The second section is dedicated to the methodological apparatus and section 3 presents the results obtained in the assessment of the ethical managerial posture of business leaders in Senegal.

\section{The business ethics in question?}

De George (1990) defines ethics as "a systematic attempt to give meaning to individual and social moral experiences, so as to determine the rules that should govern the human conduct, the fundamental values and the character traits to be developed in life". Business ethics is the branch of ethics, in other words the field bounded by the junction between ethics and business. Ethics found at the base of the company's management, that of the behavior's choice acceptable or not according to the values of society (Pasquero, 2007). 
Analyzing managerial ethics return to question the values that govern and guide the decisions of leaders. Basically, two models are opposed: the economists' posture ingrown by a purely financial rationality and the posture resulting from the CSR and ethics 'movement marked by a great social purpose.

\subsection{Posture of Economists}

The first supporters of these currents are the neoclassical economists who aim to demonstrate the primacy of an economy based on the pure and perfect competition 'principles, the private individuals 'initiative with unlimited rationality driven by alone the pursuit of interests and absolute confidence in the regulatory mechanisms of the market. Their economic philosophy is based on a world 'idea entirely based on private exchanges and that the market is the only organization' form that must be at the center of economic dynamics. The state is viewed with suspicion as a carrier and creator of distortions on the market (Friedman, 1971), of artificial conflicts in the sphere of private commercial relations (Hayek, 1943). The freedom' principle is the pivot of the market economy. The state must only ensure equal opportunities so that everyone has the same chances to access to prosperity. However, Galbraith who believes in the regulatory role of the welfare state assumes that it is the government' hand through state regulation that moralizes the companies' behavior. Moreover, in a Smith vision, the pursuit of individual interest would bring us closer to a harmony of society, through an invisible hand of the market. Proponents of liberalism reject any state intervention deemed ineffective or even harmful because imposing additional constraints on the market or even restricting the economic freedoms of agents. They ensure that the only social responsibility of companies is to guarantee the shareholders' interest. Also the company's goal is to maximize profit. Milton Friedman, Nobel economist in "The New York Times Magazine, Sept. 13, 1970" illustrates perfectly: "The corporate social responsibility is to make profits (...) the modern company has no responsibility social to the public, its only social responsibilities are the fiduciary income it provides to its owners."

The agency theory is offered as a framework for studying the relationship between shareholders and leaders whose interests differ. If the manager may have responsibilities, these one act out in the context of the agency relationship, linking him to the shareholder (principal) with whom he is the agent. The agency theory of Jensen and Meckling is the foundation, through the agency relationship defined as "the contract by which one or more persons, the principal, engage another person, the agent, to perform in his name and on his behalf any task which involves the delegation of a certain power of decision to the agent "(Jensen and Meckling, 1976).

Going beyond the pursuit of profit for behalf of the owners, by devoting money to the concerns of social responsibility, the manager spends the shareholders' money, or, as the case may be, that of its customers or its employees. On the other hand, if the leader could spend the money of his shareholders, customers or employees, what capacity or legitimacy would he have to make the necessary choices? (Friedman, 1970). Friedman insists on the impossibility for the salaried and non-owner manager of the company to be responsible by spending the money of others. In this sense, CSR is "fundamentally subversive" in the eyes of economists, who adds that "the only social responsibility of the company is to use its resources and engage in activities to increase its profits in accordance with the rules of the game, that is, open and free competition without deception or fraud "(Friedman, 1970). The primacy of this shareholder vision is reaffirmed by (Jensen, 2002), who also argues that the long-term increase in the company's market value should, under certain conditions, lead to the increase in the collective well-being.

In the perspective of liberalism, the primary function of the economy is to satisfy the material needs of humans, and the induced rationality is purely financial. The resulting managerial posture rests first and foremost as the notion of profitable behavior. It favors selfishness and the materialism of money. To think in a manager is to think profit, it is to think efficiency: the immutable rule obeys to the satisfaction of self-interest and profitability. The management sciences' eruption was therefore intended primarily to introduce rationality within private enterprises in order to improve their profits and productivity. We do not do business with good feelings. The world business is a field of hard clashes between competitors where only the strongest survive on the market and the others disappear. Consequently, the introduction of the moral rule limits the possibilities of action or prohibits certain behaviors.

\subsection{Posture based on CSR and ethics}

In recent years, the resounding financial scandals (Enron, WorldCom, Parmalat, Ahold, ...), the persistent stock market crises and the serious ecological dramas that continue to destroy the ecosystem and struck the collective human conscience. 
According to IPCC, $60 \%$ of ecosystems are exploited beyond their capacity, $75 \%$ of fish stocks are overfished and 36.6 million hectares of forests have disappeared in the last five years. The concentration of carbon dioxide in the atmosphere has increased by $40 \%$ compared to the twentieth century. On the other hand, one billion people are considered very poor and the capitalist model exacerbates inequalities in the world. On this theme, the Oxfam report of 2017 shows that since 2015, the richest $1 \%$ hold as much wealth as the rest of the planet, and at present only eight men hold as much wealth as the poorest half of the world population. As a result, the emergence of these modern global ethical issues with major environmental threats makes the acceptance of the traditional capitalistic vision morally unbearable. The acuteness of the debate on CSR or sustainable development responds to an essential concern that would be an incentive for the paradigm change held by ethics. Thus, the introduction of ethics as a new founding paradigm in management is far from being neutral, but acts as a regulation of the liberal economy. It seems that through CSR, the object is to rebuild the legitimacy of companies and to recreate their confidences lost in the deregulation of the liberal economy.

That is to say that ethics has become today the pivot value or the compass value that allow to face with the excesses of economic capitalism. If economic values are embodied by materialism and the power of money, respect for the human and nature is fundamentally linked to vital values since our destiny is conditioned by the existence of our planet. When the ethical questioning deals with the consequences of the activities for others and the assumption of the general interest by the organizations with regard to their preponderant role as social institution, appears the notion of social responsibility of the company. Managerial ethics looms basically the social responsibility of the company.

CSR as an ethics of corporate responsibility is an instrument of governance by a generalization of the theory of the agency. The company is seen as an implicit or explicit node of contracts that connects several actors (shareholders, creditors, employees, consumers, suppliers, communities, NGOs ...) The leader thus becomes the receptacle of a multitude of solicitations that it will have to satisfy by a subtle balancing of the divergent each actor' expectations. CSR then evolves into a governance tool soaked by the decline of the shareholder model in favor partnership model (Charreaux and Desbrières, 1998, Rajan and Zingales, 1998).

Porter (2014) ensures that CSR provides the opportunity to create economic value by creating social value. This CSR raises a question of responsibility, which consists of responding to the meaning of its commitments and their consequences. For the company, the main concern is to put these new ethical constraints in its major goal of maximizing profit. The assumption of the common interest comes to slow down the exclusive pursuit of the particular interest. Managerial ethics becomes a field of tension at the interface of the particular interests of the shareholders of the company, the general interest and the interests of others.

Managerial ethics has to be conceived in the frame of performance. The fundamental problem that arises is how managers should reconcile profit maximization with respect for others. Carroll $(1979,1991)$ was the first to formulate a pyramid model of social responsibility with interlocking that successively covers the economic, legal, ethical and discretionary expectations that society has at a given moment. Yet Carroll's pyramid of CSR suggests economic values come before ethical. In 2016, Carroll reprecises and moderates this by arguing that ethical responsibility should be seen as a factor that cuts through and saturates the entire pyramid. He augments that economic and legal responsibilities are required, ethical and philanthropic responsibilities are expected and desired.

Goodpaster (1991) advocates another approach that is in fact a soften shareholder view: "The company has responsibilities to its Stakeholders, but they are not fiduciary. The company has mainly an economic mission, constrained by ethical obligations ". In this case, the ethical posture of leaders should be governed by the search for economic efficiency under the constraint of ethical obligations. However, some CSR researchers such as Kang (1995) argue the opposite, that is, companies were only free to make profits after they complied with ethical and legal requirements and not the other way around. In other words, ethical considerations should take precedence over the pursuit of economic efficiency.

Visser (2005) provides proof of a CSR model in African' context, that conclude "argument could be made that improved ethical responsibilities, incorporating good governance, should be assigned the highest priority in Africa, since this provides the key to improvements in all the other dimensions, including economic development, rule of law and voluntary action.(Visser, 2005)" 
On another repository, Nalband and Kelabi (2014) propose a universal CSR's model which dictates that it is the legal responsibility which ought to be addressed first then the rest, economical, ethical and philanthropic may be in a hierarchical way or in a multiple manner as per the beliefs, values and assumptions of top management/ strategist.

Baden (2016) offers an amended pyramid of CSR that places ethical responsibilities as primary, followed by legal responsibilities economic responsibilities and lastly philanthropy. Beyond the four levels of responsibility defined since Carroll 1979, our central preoccupation is to understand which of the traditional economic values favoring the profit's maximization or ethical values encouraging firms in the CSR pathway take precedence for managers today in their decision making. So, the major problematic of this paper is to explain the managerial posture of Senegalese managers and to appreciate its inclination according ethics and CSR's ideals or profit's maximization values.

\section{Research Methodology}

In the frame of this research, we will examine the managerial posture of business leaders in Senegal. We will appreciate their principles of managerial involvement that embody their freedom and their individual responsibility to decide and act within the limits of economic or ethical constraints. We will seek to understand the perception of managers as to the scope of the responsibility of their organization. Based on the PLS approach of the structural equation methods, we will model the direction of the responsibility of the Senegalese managers according to the two traditional visions developed in the first theoretical part of this article:

1. A profit orientation that symbolizes the vision of classical economic theories

2. Ethical and CSR orientation centered on social voluntarism

Based on Miles \& Huberman's (1991) paradigm of « logical positivism arranged", we adopted a hypotheticodeductive approach to confront the PRESOR ${ }^{1}$ tool "Perceived Role of Ethics and Social Responsibility" with the reality of empirical observations, through a survey in Senegal. Also, our methodological approach is articulated in two phases: an exploratory phase and a confirmatory phase.

\subsection{Exploratory Analyzes}

In the exploratory phase, the prime question will be whether the data obtained are suitable for factor analysis. Two statistical tests will then be mobilized: the KMO index ("Kaiser-Meyer-Olkin") or MSA ("Measure of Sampling Adequacy") and the Bartlett test. The MSA reflects the relationship between the correlations between the variables on the one hand and the partial correlations on the other, reflecting the uniqueness of the contribution of each variable. The Bartlett test verifies the hypothesis of a correlation matrix equal to an identity matrix. Then, in order to appreciate the number of significant component to retain and the unidimensionality of the constructs, we will combine a principal component analysis (PCA) seeking a solution to all the variance of the measured variables to a Principal factor analysis (PFA) exploring a solution to the covariance between the measured variables. We will first perform an orthogonal rotation PCA (varimax) by letting the procedure define the number of default factors and using several criteria to examine the dimensionality of the scale. These criteria are summarized in the following:

1. The criterion of eigenvalues: it is a question of retaining the factors whose eigenvalue is superior to 1 . A eigenvalue represents the total variance explained by each factor.

2. The Kaiser-Guttman rule: if the variables are independent two by two, the eigenvalues $\lambda_{\mathrm{k}}$ would all be equal to 1 . The first eigenvalue $\lambda_{1}$ of the block ACP must be greater than 1, the others are less than 1 .

3. The Karlis-Saporta-Spinaki rule: make the Kaiser-Guttman rule stricter by taking into account the characteristics ( $\mathrm{n}$ and $\mathrm{p}$ ) of the data.

$$
\begin{gathered}
\text { Équation } 1 \text { : Karlis-Saporta-Spinaki Rule } \\
\qquad \lambda>1+2 x \sqrt{\frac{p-1}{n-1}}
\end{gathered}
$$

4. Test of the "Broken-stick critical values" of Frontier (1976) and Legendre-Legendre (1983): if the inertia was distributed randomly on the axes, the distribution would follow the law of the "broken sticks".

\footnotetext{
${ }^{1}$ The perceptual scale PRESOR is developed by Singhapakdi et ali (1996)
} 


\section{Equation 2: The "broken sticks" test of Frontier (1976) and Legendre-Legendre (1983)}

The component is validated if: $: \lambda_{k}>b_{k}$

$$
b_{k}=\sum_{m=1}^{p} \frac{1}{m}
$$

5. The Scree plot: observes the eigenvalue curve in descending order. The number of factors to remember is at the highest angle on the percentage curve.

6. The percentage of the variance returned: it is a question of measuring the percentage of the variance recovered by the set of items. Igalens and Roussel (1998) place this threshold at around 50\%. Philippeau (1986) proposes the following thresholds: Variance explained> 0.8 , the variable is very well represented;0.65 <explained variance $<0.8$, the variable is well represented; $0.40<$ explained variance $<0.65$, the variable is moderately represented.

7. Examination of the correlation matrix: The final step in principal component analysis is to test the factor structure obtained by examining the correlation matrix. In the case of unidimensionality, each variable must be more correlated to its main component than with the other components. The rule is to eliminate items with a loading less than 0.5 or having a high factor score greater than 0.5 on several significant axes. The examination of the correlation coefficients or loadings must be realized in connection with their square cosines which symbolize the quality of representation of the variable on the component. This quality of representation is the information of the modality reproduced by the axis and indicates the inertia of the modality on the axis divided by the total inertia of the modality.

After this ACP which is interested in the total variability of the variables, we will mobilize PFA which corresponds more to a modeling approach. According to Rakotomalala (2013), PFA is a preferable approach when structuring information. In addition, we will be attentive to the index of reliability of the factor in the PFA which corresponds to the credibility of the projection of the individuals in the factorial coordinate system. The reliability indicator of the factor coincides with the square of the correlation between the theoretical latent variable (to be estimated) and its estimation by the factor. The closer it is to 1 , the more credible the factor. The further away from 1, the less interesting is the factor. A reliability indicator of the higher factor $(\geq 0.7)$ indicates a good stability of the factor (Rakotomalala, 2013).

We will conclude the exploratory study by examining the reliability of a measuring instrument that represents its ability to reproduce similar results if it was administered several times to the same population (Roussel, 1996). The most widely used tool for measuring reliability is Cronbach's $\alpha$ (1951), which appreciates the variation in the total score of the scale due to all common item factors. Nunnally (1978) suggests that a Cronbach's alpha between 0.6 and 0.7 allows concluding to a good internal consistency of the scales. All analyzes of the exploratory phase will be carried out with the free software of Data Mining Tanagra. The managerial posture of leaders is composed of two dimensions: "Profit Orientation" and "Ethical and CSR Orientation". The analyzes will be conducted taking into account both dimensions.

- Profit Orientation: Consisting of items PIM1, PIM2, PIM3, PIM4 and PIM5, it indicates a management of leaders rather focused on the satisfaction of the concerns of its own organization and the maximization of profit.

- Ethical and CSR Orientation: Made up of items PIM6, PIM7, PIM8, PIM9, PIM10, PIM11, and PIM12. She indicates a management rather forthcoming on Ethics and CSR.

\subsection{Confirmatory Analyzes}

In the confirmatory phase, we opted for structural equation methods with the use of the PLS-PM module of the XLSTAT software, which was developed by Addinsoft in 1996. Structural equation methods can estimate predictive validity of the construct by confirming that the factor structure is adapted, both from a statistical and a conceptual point of view. "If the validity of the models of factorial structures is recognized, then a new proof of the construct validity of the questionnaire is provided" (Roussel, 1996). There are two families of modeling by the structural equations system (Stan and Saporta, 2006, Jacobowics, 2007 and Lacroux, 2009): the LISREL method and the PLS method that can be considered complementary. The LISREL method (Jöreskog et al., 1982) is an approach that consists in modeling the structural equations by the maximum likelihood. It is statistically based on the analysis of the covariance structure. 
The PLS method (Partial Least Square) introduced by (Wold, 1975, 1985), is a modeling approach that consists in minimizing the residual variances under the constraint of the fixed point. PLS is more adapted to the specificities of our approach than the LISREL approach. As indicated Wold (1975), PLS is a "soft modeling" approach with very few distribution hypotheses and the sufficiency of a few data for its mobilization as opposed to the LISREL structural equation models, which are qualified as "hard modeling" with heavy distribution assumptions and several hundred necessary cases.

In this study, the sample size is modest (119 individuals) and the PLS approach frees us from the constraints of verifying the normality of our data. The validation of the results with the PLS approach supposes on the one hand the estimation of the measurement model (external model) resulting in the relations between the constructs and their indicators, and on the other hand the structural model (internal model), which carries the relations between the constructs.

In estimating our measurement model, we mobilize only reflexive constructs that assume that the indicators (or items) are the effects of these underlying constructs, to which they are attached. The causal relationship takes place from the construct to its indicators. The evaluation of reflexive constructs is done by examining their reliability and validity of construct including the estimation of their convergent and discriminant validity.

The estimation of our measurement model (external model) begins with the analysis of the composite reliability index such as Dillon and Goldstein's rhô (DG's rhô) which is more significant in PLS models (Chin et al., 2003, Tenenhaus et al., 2005). It is presented as being less dependent on the number of items, more robust than Cronbach's alpha (Peterson, 1994) and more suitable for second-generation multivariate analysis. It is also necessary to test the validity of the measuring instruments. The trait validity allow to check whether the items give a better representation of the phenomenon studied and also to check whether the items are correlated or different (Evrard et al., 2009). It is a question of checking the aptitude of the measuring instrument to appreciate precisely and only the studied constructs. The validity of the construct covers convergent validity and discriminant validity.

Convergent validity tests the degree to which two measures of the same concept by two different methods are convergent, that is, two measures of the concept by two different methods are effective. It evaluates the correlation between the indicators of the same construct through two elements (Chin, 2010, Hair et al., 2014). First the loadings of each indicator of a construct that must be significant, that is to say that their value must be greater than or equal to 0.5. Then, the Average Variance Extracted (AVE), also called the convergent validity $\rho$ (Fornell and Larcker, 1981) must be greater than 0.5 (Chin, 1998). The latent variable must be more strongly correlated with its own observable variables than with the other items.

Discriminant validity tests "the degree to which a concept differs from others" (Drucker-Godard et al., 2008: 265). Otherwise, the discriminant validity allows measuring the strength of the relations between the manifest variables (items) and their latent variables (concepts) with respect to their relations with the other latent variables. It is evaluated in two stages according to (Chin, 2010, Hair et al., 2014):

1. The examination of the "cross loadings" of all the indicators of the model, which makes it possible to verify that the correlations for each construct with the other constructs of the model. He postulates that the loading of each indicator must be greater than its cross-loadings (Chin, 1998);

2. The Fornell-Larcker criterion, which compares the square root of the AVE with the correlations between of a model constructs. The square root of the AVE must be greater than the highest correlation of one construct with another.

The estimation of our structural model (internal model) deals with the relationships between the latent variables and validates the research hypotheses. Thus, the estimation of the structural model makes it possible to test hypotheses. PLS is a non-parametric approach, so parametric significance tests can'not be applied. However, PLS PM from XLSAT provides a necessary Bootstrapping procedure to test the significance of the coefficients. In our work, the size unit of the bootstrap resampling procedure is set to 500 .

Unlike the covariance structure analysis method (LISREL), the PLS approach does not optimize any criterion or index allowing a global validation of the model. However, Amato, Esposito Vinzi and Tenenhaus, (2004) highlight the global goodness of fit $(\mathrm{GoF})$ criterion, which represents a global validation measure of the model. The closer it is to 1 , the better the quality of the model is or at least greater than or equal to 0.5 (Tenenhausand al, 2005). 
Latan and Ghozali (2012) suggest three (3) intervals to appreciate the GoF: 1) a GoF less than or equal to 0.10, indicates a low quality; 2) a GoF between 0.1 and 0.25 indicates an average quality; 3) a GoF greater than or equal to 0.36, represents a high quality. The XLSAT PLS PM results review is based on a set of indicators that are: the level of the $\mathrm{R}^{2}$ values, the importance of the structural coefficients, the size effect $\mathrm{f}^{2}$, and the predictive relevance $\left(Q^{2}\right)$.

\section{Examination of the coefficients of determination $\mathrm{R}^{2}$}

The calculation of $\mathrm{R}^{2}$ is done only for endogenous latent variables that facilitate the measurement of correlations between latent variables. In other words, the $\mathrm{R}^{2}$ makes possible to understand how each explicative variable contributes to the prediction of its dependent variable. A value close to 1 indicates a high level of accuracy. The $\mathrm{R}^{2}$ must be compared to the adjusted $\mathrm{R}^{2}$ that slicks the biases inherent in complex models. If these two indicators are similar or very similar, this suggests that the model is stable.

\section{Review of structural coefficients}

The causal model is estimated by examining its parameters (path coefficients) and their level of significance. The coefficients are interpreted as the coefficients of a regression model and reflect the measure of the relation between the constructs. The higher the absolute value of a coefficient, the larger the weight of the corresponding variable.

3. Appreciation of the effect size $\mathrm{f}^{2}$

The effect of size $\mathrm{f}^{2}$ permits to measure the impact of a variable in the explanation of an endogenous latent variable. It evaluates the proportions in which an exogenous construct contributes to the $\mathrm{R}^{2}$ of an endogenous construct or the impact of the omission of a construct on the endogenous construct. According to Cohen (1988) and Hair et al. (2014): 1) a $\mathrm{f}^{2}$ lower than 0.02 indicates a weak effect; 2) a $\mathrm{f}^{2}$ between 0.02 to 0.35 represents a moderate effect; and 3) a f ${ }^{2}$ superior than 0.35 represents a high effect.

\section{Findings or Search Results}

\subsection{Result of the exploratory phase}

Conclusion on the factorial solution of the exploratory phase "Posture ethics managerial" or in other words "Individual Principle of managerial discretion" of leaders in Senegal

The analyzes are conducted according to the methodology described in section 2.1 and a summary of the principal components and factor analyzes after iterations are presented in Appendix 1. The results show the unidimensionality and the good factorial adequacy of the "Orientation Profit" construct that will be retained with PIIM1, PIIM2, PIIM3 and PIIM4. Similarly, they also confirm the unidimensionality and the good factorial adequacy of the construct "Orientation Ethics and CSR" which will be retained with the items PIIM10, PIIM6, PIIM7 and PIIM

Table 1: Summary of the results of the exploratory analyzes

\begin{tabular}{|c|c|c|c|c|c|c|c|c|}
\hline \multicolumn{9}{|c|}{ ETHICAL POSTURE OF MANAGERS } \\
\hline Dimension & Variables & $\begin{array}{l}\text { Item } \\
\text { retained }\end{array}$ & $\begin{array}{l}\text { Item } \\
\text { Number }\end{array}$ & $\begin{array}{l}\text { KMO } \\
\text { Indice }\end{array}$ & $\begin{array}{l}\text { Explained } \\
\text { Variances }\end{array}$ & $\begin{array}{c}\text { Cronbach } \\
\text { alpha }(\alpha)\end{array}$ & $\begin{array}{l}\text { Index } \\
\text { reliability of } \\
\text { the factor }\end{array}$ & Status \\
\hline \multirow{2}{*}{$\begin{array}{c}\text { Individual } \\
\text { Principle } \\
\text { of Managerial } \\
\text { Involvement }\end{array}$} & $\begin{array}{l}\text { Orientation } \\
\text { Profit }\end{array}$ & $\begin{array}{l}\text { PIM1 } \\
\text { PIM2 } \\
\text { PIM3 } \\
\text { PIM4 }\end{array}$ & 04 & 0,776 & $54,76 \%$ & 0,724 & 0,668 & Valid \\
\hline & $\begin{array}{l}\text { Orientation } \\
\text { Ethics and } \\
\text { CSR }\end{array}$ & $\begin{array}{l}\text { PIM6 } \\
\text { PIM7 } \\
\text { PIM8 } \\
\text { PIM10 }\end{array}$ & 04 & 0,653 & $60,20 \%$ & 0,778 & 0,756 & Valid \\
\hline
\end{tabular}




\subsection{Result of the confirmatory phase}

\section{Examination of the measurement model}

\section{Confirmatory analysis of reliability and convergent validity}

The confirmatory analysis of the reliability of ethical posture of managers in Senegal shows satisfactory unidimensionality of the "Profit Orientation" and "Ethical Orientation and CSR" constructs with Cronbach $\alpha$ and higher DG values> 0.7. This unidimensionality is confirmed by the Kaiser criterion (first eigen value greater than 1 and the others less than 1 on each block of variables). The results also certificate the convergent validity. The factor loadings, expressed by the PLS algorithm, allow to conclude to a good convergent validity of the constructs of the scale "Principle of managerial implication" because all its two dimensions have a score higher than 0.7 . The convergent validity of the scale is also confirmed on all its dimensions by the $\rho$ of convergent validity of (Fornell and Larcker, 1981) or (AVE) all greater than 0.5.

Table 2: Analysis of reliability and convergent validity of the scale

\begin{tabular}{|c|c|c|c|c|c|c|c|}
\hline \multicolumn{8}{|c|}{ RELIABILITY ANALYSIS } \\
\hline Latent variable & Dimension & $\begin{array}{l}\text { Manifest } \\
\text { Variables }\end{array}$ & $\begin{array}{l}\text { Cronbach } \\
\text { alpha }(\alpha)\end{array}$ & $\begin{array}{l}\text { D.G's } \\
\text { Rho }\end{array}$ & Eigen Values & Loadings & Average Community \\
\hline \multirow{4}{*}{$\begin{array}{c}\text { ORIENTATION } \\
\text { ETHICS AND } \\
\text { CSR }\end{array}$} & \multirow{4}{*}{4} & PIM10 & \multirow{4}{*}{0,778} & \multirow{4}{*}{0,858} & 2,408 & 0,805 & \multirow{4}{*}{0,601} \\
\hline & & PIM6 & & & 0,667 & 0,820 & \\
\hline & & PIM7 & & & 0,620 & 0,736 & \\
\hline & & PIM8 & & & 0,305 & 0,737 & \\
\hline \multirow{4}{*}{$\begin{array}{l}\text { ORIENTATION } \\
\text { PROFIT }\end{array}$} & \multirow{4}{*}{4} & PIM1 & \multirow{4}{*}{0,724} & \multirow{4}{*}{0,829} & 2,190 & 0,736 & \multirow{4}{*}{0,546} \\
\hline & & PIM2 & & & 0,684 & 0,696 & \\
\hline & & PIM3 & & & 0,609 & 0,775 & \\
\hline & & PIM4 & & & 0,517 & 0,747 & \\
\hline
\end{tabular}

\section{Examination of divergent validity}

The examination of the "Cross Loadings" shows the discriminant validity is proven for all the two dimensions of the "Principle of managerial implication" scale since the correlations the set of items are higher with the constructs to which they are attached. The results also indicate that the AVE for each factor exceeds the squares of the correlations between the factors two by two, which confirms the discriminant validity of the two dimensions of the "managerial ethical posture" scale.

Table 3: Examination of divergent validity

\begin{tabular}{|l|c|c|}
\hline Latent variable & $\begin{array}{c}\text { ORIENTATI } \\
\text { ON ETHICS } \\
\text { AND CSR }\end{array}$ & $\begin{array}{c}\text { ORIENTATI } \\
\text { ON PROFIT }\end{array}$ \\
\hline $\begin{array}{l}\text { ORIENTATION ETHICS AND } \\
\text { CSR }\end{array}$ & $\mathbf{1}$ & 0,025 \\
\hline ORIENTATION PROFIT & 0,025 & $\mathbf{1}$ \\
\hline Average Community (AVE) & $\mathbf{0 , 6 0 1}$ & $\mathbf{0 , 5 4 6}$ \\
\hline
\end{tabular}

\begin{tabular}{|c|c|c|}
\hline & $\begin{array}{c}\text { ORIENTATION } \\
\text { ETHICS AND } \\
\text { CSR } \\
\end{array}$ & $\begin{array}{l}\text { ORIENTATION } \\
\text { PROFIT }\end{array}$ \\
\hline PIM10 & 0,805 & $-0,063$ \\
\hline PIM6 & 0,820 & $-0,183$ \\
\hline PIM7 & 0,736 & $-0,178$ \\
\hline PIM8 & 0,737 & $-0,043$ \\
\hline PIM1 & $-0,031$ & 0,736 \\
\hline PIM2 & $-0,068$ & 0,696 \\
\hline PIM3 & $-0,214$ & 0,775 \\
\hline PIM4 & $-0,121$ & 0,747 \\
\hline
\end{tabular}

\section{Review of the structural model}

The results show that the research model must be retained $(\mathbf{G o F}=\mathbf{0 . 6 7 2})$ in terms of the threshold $(\mathbf{G o F} \geq \mathbf{0 . 5})$ recommended by Tenenhaus et al (2005). Absolute and relative Gof, based on internal and external models that are very high and close to their bootstrap estimates, suggest a good fit of the model to the data and its relative stability. In addition, the evaluation of the structural model through the examination of research hypotheses can be viewed from Equation1. 


\section{Équation 1: Modelization Ethical posture of Senegalese managers}

ETHICAL POSTURE ( PRINCIPLE OF MANAGERIAL IMPLICATION) OF SENEGALESE MANAGERS

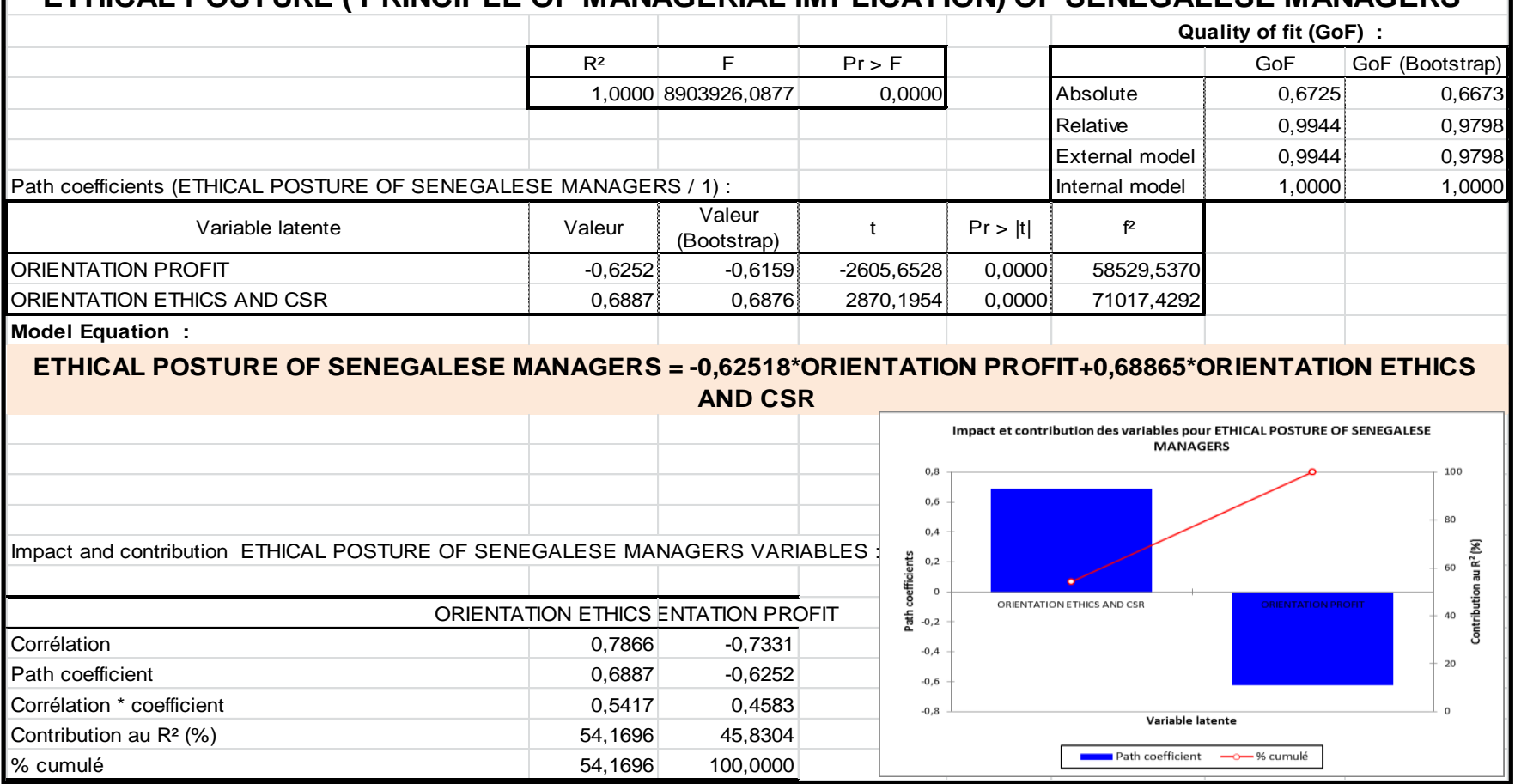

The endogenous variable "Principle of managerial implication" shows an excellent modeling quality with a coefficient of determination $\mathrm{R}^{2}$ very close to $1(0.999)$. The results indicate that the model is fairly stable because its $\mathrm{R}^{2}$ coefficient of determination and the values of the exogenous variables vary very near from their values after the bootstrap resampling procedure at 500 iterations.

The analysis of the regression links of the «Principle of managerial implication» reveals also very interesting results. In fact, it first states that "Ethical Orientation / CSR" explains and determines in the first instance "Principle of managerial implication" as evidenced by the significant values of the path coefficients at 0.689 , of the $\mathrm{p}$ value $(\mathrm{Pr}>\mathrm{t}$ to $95 \%)$, of significant size effect $(>0.35)$ and of the substantial contribution to the coefficient of determination $\mathrm{R}^{2}$ (of $54 \%$ ).

The analysis indicates that the importance of "Orientation Ethics / CSR" on the "Principle of managerial implication» is moderated by "Orientation Profit". This "Profit Orientation" has a negatively limited influence on the "Principle of managerial implication" with appreciable values of the standardized regression coefficient (0.625) with a value value of $95 \%(\operatorname{Pr}>t)$, large size effect $(>0.35)$ and a contribution to the coefficient of determination $\mathrm{R}^{2}$ ( of $45 \%$ ). These results suggest that the top managers questioned in our study in Senegal have a principle of managerial discretion guaranteeing their individual freedom to decide and act, more oriented towards ethics and CSR than the outrageous research of profit maximization of their respective companies.

\section{Conclusion}

In this article, we have modeled and measured "Principle of managerial implication" of firm's leaders in Senegal with the two-dimensional perceptual scale PRESOR. The results garnered invalidate the neoclassical theses according to which the sole responsibility the company is to guarantee the sole interest of the shareholders. In fact, for ultraliberal capitalism, the only vocation of the company is the profit purpose and the ethical posture of the leaders should be centered on the achievement of efficiency and profitability. Our results indicate beyond existence, the prominence of the dimension "ethical orientation / CSR" in the managerial posture of business leaders in Senegal. They indicate the primacy of "Ethical Orientation / CSR" in the determination of our model of responsibility. Our research model mitigates Goodpaster's conclusions, refutes the pyramid of responsibilities proposed by Carroll $(1979,1991)$ and goes in the direction of Baden works (2016). 
However, it would be possible to obtain a conciliatory reading of all these contradictory results. These divergences would mainly reflect a current evolution of managers' perception of their roles and the extent of their responsibility in view of the prominence of the CSR debate.

\section{Bibliography}

Carroll A.B. (1979), « A Three Dimensional Conceptual Model of Corporate Performance », Academy of Management Review, vol. 4, n 4, p. 497-505.

Carroll, A. B. (1979). A three-dimensional conceptual model of corporate performance. Academy of management review, 4(4), 497-505.

Carroll, A. B. (1991). The pyramid of corporate social responsibility: Toward the moral management of organizational stakeholders. Business horizons, 34(4), 39-48.

Carroll, A. B. (2016). Carroll'spyramid of CSR: taking another look. International journal of corporate social responsibility, 1(1), 3 .

Charreaux, G., \& Desbrières, P. (1998). Gouvernance des entreprises: valeur partenariale contre valeur actionnariale. Finance contrôle stratégie, 1(2), 57-88.

Chin, W. W. (1998). The partial least squares approach to structural equation modeling. Modern methods for business research, 295(2), 295-336.

Chin, W. W. (2010). How to write up and report PLS analyses. In Handbook of partial least squares (pp. 655690). Springer, Berlin, Heidelberg.

Chin, W. W., Marcolin, B. L., \& Newsted, P. R. (2003). A partial least squares latent variable modeling approach for measuring interaction effects: Results from a Monte Carlo simulation study and an electronic-mail emotion/adoption study. Information systems research, 14(2), 189-217

Cohen J,1988. Statistical Power Analysis for the Behavioral Sciences, 2nd ed. Hillsdale, New Jersey: Erlbaum.

De George, R. T. (1990). Using the techniques of ethical analysis in corporate practice. In People in Corporations (pp. 25-33). Springer, Dordrecht.

Drucker-Godard, C., Ehlinger, S., \& Grenier, C. (1999). Validité et fiabilité de la recherche. Méthodes de recherche en management. RA Thiétart. Paris, Dunod.

Englander, E., \& Kaufman, A. (2004). The end of managerial ideology: From corporate social responsibility to corporate social indifference. Enterprise \& Society, 5(3), 404-450.

Evrard, Y., Pras, B., Roux, E., Desmet, P., Dussaix, A. M., \&Lilien, G. L. (2009). Market-Fondements et méthodes des recherches en marketing (No. hal-00490724).

F. Hair Jr, J., Sarstedt, M., Hopkins, L., \& G. Kuppelwieser, V. (2014). Partial least squares structural equation modeling (PLS-SEM) An emerging tool in business research. European Business Review, 26(2), 106-121.

Fornell, C., \&Larcker, D. F. (1981). Structural equation models with unobservable variables and measurement error: Algebra and statistics. Journal of marketing research, 382-388.

Friedman, Milton, "The Social Responsibility of Business Is to Increase Its Profits", 13 septembre 1970, The New York Times Magazine, pp. 32-33, 122-124.

Frontier, S. (1976). Étude de la décroissance des valeurs propres dans une analyse en composantes principales: Comparaison avec le modèle du bâton brisé. Journal of experimental marine Biology and Ecology, 25(1), 67-75.

Goodpaster, K. E. (1991). Business ethics and stakeholder analysis. Business ethics quarterly, 53-73.

Hayek, F. A. (1943). A commodity reserve currency. The Economic Journal, 53(210/211), 176-184.

Igalens, J., \& Roussel, P. (1998). Méthodes de recherche en gestion des ressources humaines. Economica.

Jakobowicz, E. (2007). Contributions aux modèles d'équations structurelles à variables latentes (Doctoral dissertation, Conservatoire national des arts et metiers-CNAM).

Jensen, M. C. (2002). Value maximization, stakeholder theory, and the corporate objective function. Business ethics quarterly, 235-256.

Jensen, M. C., \& Meckling, W. H. (1976). Theory of the firm: Managerial behavior, agency costs and ownership structure. Journal of financial economics, 3(4), 305-360.

Jöreskog, K. G., \& Sörbom, D. (1982). Recent developments in structural equation modeling. Journal of marketing research, 404-416.

Kang, Y. C. (1995). Before-profit CSR, stakeholder capitalism and just enterprise system (Doctoral dissertation, University of Pittsburgh). 
Lacroux, A. (2009). L'analyse des modèles de relations structurelles par la méthode PLS: une approche émergente dans la recherche quantitative en GRH. XXème congrès de l'AGRH, Toulouse du, 9.

Latan, H., \& Ghozali, I. (2012). Partial Least Squares: Concept. Technique and Application Using Program Smart PLS for Empirical Research, BP UNDIP.

Lawson, M., \& Martin, M. (2017). The Commitment to Reducing Inequality Index: A new global ranking of governments based on what they are doing to tackle the gap between rich and poor. Oxfam.

Legendre, L., \& Legendre, P. (1983). Measures of ecological resemblance. Legendre, L., Legendre, P. Numerical ecology. Elsevier Scientific Publishing Company, Amsterdam, 317p.(Developments in environmental modeling, n. 3).

Miles, M. B., \& Huberman, A. M. (1991). Analyse des données qualitatives: recueil de nouvelles méthodes. De Boeck et Larcier.

Nalband, N. A., \& Kelabi, S. A. (2014). Redesigning Carroll's CSR pyramid model. Journal of Advanced Management Science, 2(3).

Nunnally, J. (1978). Psychometric methods

Pasquero, J. (2007). Commentaire: Éthique des affaires, responsabilité sociale et gouvernance sociétale: démêler l'écheveau. Gestion, 32(1), 112-116.

Peterson, R. A. (1994). A meta-analysis of Cronbach's coefficient alpha. Journal of consumer research, 21(2), 381-391.

Philippeau, G., \& Philippeau, G. (1986). Comment interpréter les résultats d'une analyse en composantes principales?. Institut technique des céréales et des fourrages (ITCF).

Porter, M. E. (2014). Kramer. MR (2011) Creating Shared Value: How to reinvent capitalism-and unleash a wave of innovation and growth. Harvard Business Review (HBR), January/February, HBR, 1-17.

Rajan, R. G., \&Zingales, L. (1998). Power in a Theory of the Firm. The Quarterly Journal of Economics, 113(2), 387-432.

Rakotomalala, R. (2013). Comparaison de populations: Tests paramétriques. Bartlett test, 7, 27-29.

Rakotomalala, R. Université Lumière Lyon 2. Analyse de corrélation. Étude des dépendances-Variables quantitatives.

Roussel P. (2005), « Méthodes de développement d'échelles pour questionnaires d'enquête », in Roussel P. et Wacheux F., Management des Ressources Humaines : Méthodes de recherche en sciences humaines et sociales. Bruxelles: De Boeck, chapitre 9, p. 245-276

Singhapakdi, A., Vitell, S. J., Rallapalli, K. C., \& Kraft, K. L. (1996). The perceived role of ethics and social responsibility: A scale development. Journal of business ethics, 15(11), 1131-1140.

Stan, V., \& Saporta, G. (2006). Une comparaison expérimentale entre les approches PLS et LISREL. Actes des 38èmes Journées de Statistique.

Tenenhaus, M., Amato, S., \& EspositoVinzi, V. (2004, June). A global goodness-of-fit index for PLS structural equation modelling. In Proceedings of the XLII SIS scientific meeting (Vol. 1, pp. 739-742).

Tenenhaus, M., Vinzi, V. E., Chatelin, Y. M., \&Lauro, C. (2005). PLS path modeling. Computational statistics \& data analysis, 48(1), 159-205.

Visser, W. (2006). Revisiting Carroll's CSR pyramid. Corporate citizenship in developing countries, 29-56.

Wold, H. (1975). Pathmodels with latent variables: The NIPALS approach. In Quantitative sociology (pp. 307-357).

Wold, H. (1975). Soft modelling by latent variables: the non-linear iterative partial least squares (NIPALS) approach. Journal of Applied Probability, 12(S1), 117-142.

Wold, H. O. A. (1985). Partial least squares and LISREL models. Measuring the unmeasurable. Nijhoff, Dordrecht, Boston, Lancaster, 220-251. 


\section{Appendix 1}

Summary of the results of the Principal Component Analysis and Principal Factor Analysis of the construct "Profit Orientation"

Eigenvalue table - Test for significance

\begin{tabular}{|l|l|l|l|}
\multicolumn{2}{|c|}{ Eigenvalues - Significance } \\
Axis & Eigenvalue & $\begin{array}{l}\text { Broken-stick } \\
\text { critical } \\
\text { values }\end{array}$ & $\begin{array}{l}\text { Proportion } \\
(\%)\end{array}$ \\
\hline 1 & 2,190303 & 2,083333 & $54,76 \%$ \\
\hline 2 & 0,683539 & 1,083333 & $17,09 \%$ \\
\hline 3 & 0,609443 & 0,583333 & $15,24 \%$ \\
\hline 4 & 0,516715 & 0,250000 & $12,92 \%$ \\
\hline
\end{tabular}

Significance Principal Factor Score Coefficients of Components

\begin{tabular}{|l|c|r|r|r|r|}
\hline \multicolumn{1}{|c|}{$\begin{array}{c}\text { Global critical } \\
\text { values }\end{array}$} & \multicolumn{2}{|c|}{$\begin{array}{c}\text { Squared } \\
\text { Variables withEach Factor }\end{array}$} & 0,6681771 \\
\hline $\begin{array}{l}\text { Kaiser- } \\
\text { Guttman }\end{array}$ & 1 & Attribute & Mean & Std-dev & Axis_1 \\
\hline $\begin{array}{l}\text { Karlis- } \\
\text { Saporta- } \\
\text { Spinaki }\end{array}$ & PIM1 & 1,7394958 & 1,1914414 & 0,3021462 \\
\hline & PIM2 & 1,6302521 & 1,0913375 & 0,2518731 \\
\hline & PIM3 & 1,7563025 & 1,1073960 & 0,2755267 \\
\hline
\end{tabular}

Factor Loadings [Communality Estimates]

\begin{tabular}{l|l|l|l|l|l|l|l|l|}
\hline Attribute & \multicolumn{2}{|c|}{ Axis_1 } & \multicolumn{3}{c}{ Axis_2 } & \multicolumn{2}{c|}{ Axis_3 } & \multicolumn{2}{c|}{ Axis_4 } \\
\hline - & Corr. & $\%($ Tot. \%) & Corr. & $\%($ Tot. \%) & Corr. & $\%($ Tot. \%) & Corr. & $\%($ Tot. \%) \\
\hline PIM1 & 0,7633 & $58 \%(58 \%)$ & $-0,1674$ & $3 \%(61 \%)$ & $-0,45321$ & $21 \%(82 \%)$ & 0,4288 & $18 \%(100 \%)$ \\
\hline PIM4 & 0,7399 & $55 \%(55 \%)$ & 0,2728 & $7 \%(62 \%)$ & 0,55414 & $31 \%(93 \%)$ & 0,2663 & $7 \%(100 \%)$ \\
\hline PIM3 & 0,7395 & $55 \%(55 \%)$ & 0,4763 & $23 \%(77 \%)$ & $-0,25702$ & $7 \%(84 \%)$ & $-0,4002$ & $16 \%(100 \%)$ \\
\hline PIM2 & 0,7164 & $51 \%(51 \%)$ & $-0,5951$ & $35 \%(87 \%)$ & 0,17582 & $3 \%(90 \%)$ & $-0,3189$ & $10 \%(100 \%)$ \\
\hline Var. Expl. & 2,19030 & $55 \%(55 \%)$ & 0,68354 & $17 \%(72 \%)$ & 0,60944 & $15 \%(87 \%)$ & 0,51671 & $13 \%(100 \%)$ \\
\hline
\end{tabular}

Summary of the results of the Principal Component Analysis and Principal Factor Analysis of the construct "Ethical Orientation and CSR"

Eigenvalue table - Test for significance

\section{Eigenvalues - Significance}

\begin{tabular}{|l|l|l|l|}
\multicolumn{5}{|c}{ Eigenvalues - Significance } \\
\hline Axis & Eigenvalue & $\begin{array}{c}\text { Broken-stick } \\
\text { critical } \\
\text { values }\end{array}$ & $\begin{array}{c}\text { Proportion } \\
(\%)\end{array}$ \\
\hline 1 & 2,408163 & 2,083333 & $60,20 \%$ \\
\hline 2 & 0,666800 & 1,083333 & $16,67 \%$ \\
\hline 3 & 0,619889 & 0,583333 & $15,50 \%$ \\
\hline 4 & 0,305149 & 0,250000 & $7,63 \%$ \\
\hline
\end{tabular}

Significance Principal Factor Score Coefficients of Components

\begin{tabular}{|c|r|r|r|r|r|}
\hline $\begin{array}{c}\text { Squared } \\
\text { Variables withEach Factor }\end{array}$ & 0,7599429 & 0,0619626 & 0,0302986 \\
\hline \begin{tabular}{c} 
Attribute \\
\hline PIM10
\end{tabular} & 4,0336134 & 1,0606227 & 0,3482454 & $-0,1981636$ & $-0,0873301$ \\
\hline PIM6 & 4,2184874 & 0,9452194 & 0,3132637 & $-0,0776102$ & 0,1550909 \\
\hline PIM7 & 4,0672269 & 0,7857031 & 0,2061574 & 0,1905950 & 0,0603055 \\
\hline PIM8 & 4,2268908 & 0,8345177 & 0,2422343 & 0,1243237 & $-0,1272306$ \\
\hline $\begin{array}{c}\text { Squared Multiple Corr. of the } \\
\text { Variables withEach Factor }\end{array}$ & 0,668177 & & \\
\hline
\end{tabular}

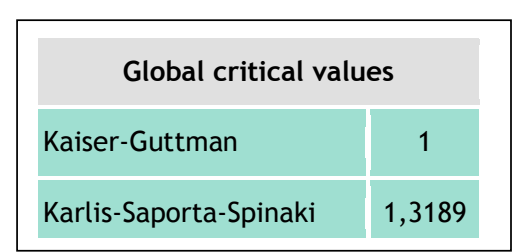




\section{Factor Loadings [Communality Estimates]}

\begin{tabular}{|l|l|l|l|l|l|l|l|l|}
\hline Attribute & \multicolumn{2}{|c|}{ Axis_1 } & \multicolumn{2}{c|}{ Axis_2 } & \multicolumn{2}{c|}{ Axis_3 } & \multicolumn{2}{c|}{ Axis_4 } \\
\hline- & Corr. & $\%($ Tot. \%) & Corr. & $\%$ (Tot. \%) & Corr. & $\%$ (Tot. \%) & Corr. & $\%$ (Tot. \%) \\
\hline PIM10 & 0,82049 & $67 \%(67 \%)$ & $-0,44328$ & $20 \%(87 \%)$ & 0,02759 & $0 \%(87 \%)$ & $-0,35993$ & $13 \%(100 \%)$ \\
\hline PIM6 & 0,80658 & $65 \%(65 \%)$ & $-0,11748$ & $1 \%(66 \%)$ & 0,48460 & $23 \%(90 \%)$ & 0,31748 & $\begin{array}{l}10 \\
\%)\end{array}$ \\
\hline PIM8 & 0,75821 & $57 \%(57 \%)$ & $-0,03077$ & $0 \%(58 \%)$ & - & $38 \%(95 \%)$ & 0,21313 & $5 \%(100 \%)$ \\
& & & & & 0,61543 & & & \\
\hline PIM7 & 0,71381 & $51 \%(51 \%)$ & 0,67495 & $46 \%(97 \%)$ & 0,07441 & $1 \%(97 \%)$ & $-0,17141$ & $3 \%(100 \%)$ \\
\hline Var. Expl. & 2,40816 & $60 \%(60 \%)$ & 0,66680 & $17 \%(77 \%)$ & 0,61989 & $15 \%(92 \%)$ & 0,30515 & $8 \%(100 \%)$ \\
\hline
\end{tabular}

Appendix 2: Research Questionnaire

\begin{tabular}{|l|}
\hline Code \\
\hline PIM1 The most important concern for a company is to make a profit, even if it means twisting the rules. \\
\hline PIM2 To remain competitive in a globalized environment, companies will have to ignore ethics and social \\
responsibility. \\
\hline PIM3 If the survival of a business is at stake, then you must forget about ethics and social responsibility. \\
\hline PIM4 Being efficient is much more important for a company than being perceived or not as ethical or socially \\
responsible. \\
\hline PIM5 Social responsibility and profitability can be compatible \\
\hline PIM6 The ethics and social responsibility of a company are primordial to its long-term profitability. \\
\hline $\begin{array}{l}\text { PIM7 The Social responsibility of a company can be determined to a large extent by the degree to which it is } \\
\text { ethical and socially responsible. }\end{array}$ \\
\hline PIM8 Business ethics and social responsibility are essential to the survival of a business. \\
\hline PIM9 The first priority of a company must be employee morale. \\
\hline PIM10 Being ethical and socially responsible is the most important thing a company can do. \\
\hline PIM11 Companies have a social responsibility beyond making a profit. \\
\hline PIM12 Good ethics is often good business. \\
\hline
\end{tabular}

